\title{
Investigate The Relationship Between Cost Management Strategy, Organization Size, Growth Options and The Performance Of Companies In Tehran Stock Exchange
}

\author{
Moslem Sedaghati ${ }^{1}$, Hamid Ravanpak Noodezh ${ }^{2}$, Ali Amiri ${ }^{3}$ \\ 1-student at master of finance ; Qeshm Higher Education Institute;IRAN \\ 2,3- Phd Accounting; Qeshm Higher Education Institute;IRAN
}

\begin{abstract}
This study aimed to investigate the relationship between cost management strategy, organization size and growth Options on the performance of the company. In this regard, the financial statements of 76 companies listed in Tehran Stock Exchange for the years 2009 to 2013 were analyzed. In this study, cost management strategy (the ratio of capital expenditure to sales, sales of the book value of fixed assets) and size (natural logarithm of total assets) and growth Options (market value of assets to book value of assets) as a variable. independent, and firm performance (return on assets, sales growth) was used as the dependent variable, so that the relationship between strategy, size, growth Options and firm performance during a 5-year period studied. The method used for data collection, library and field. To test the hypotheses of the model Autoregressive conditional heteroscedasticity (ARCH) and generalized regression model, the conditional heteroscedasticity (GARCH) were analyzed using the software Eviews8. And significance was determined using a $Z$ score and likelihood ratio. The criteria for the variable sales strategy to sell the book value of fixed assets and the capital expenditure of a significant and positive relationship with sales growth. In the capital, Tehran Stock Exchange Market participants are recommended to consider it as the time-varying volatility and time efficiencies associated with corporate assets can be public relations strategy, cost management and growth Options of the company described. Also associated with the company's sales growth can be described by the relationship between the size and cost management strategy
\end{abstract}

Key words: cost management strategy, organization size, growth Options, performance 


\section{Introduction}

When investors decide to invest, consider various factors, among them the desired performance criteria, investment decisions and therefore identifying the factors that influence on corporate performance (profitability, returns and cash flows) are very important affect a company's performance when compared with other companies will be better able to control environmental factors influencing the strategy has developed suitable and optimal supply and allocation decisions resources appropriate capital structure, capital budgeting and capital management to adopt a policy consistent with the company. The decision also assess risk. Environmental activities of the company include: 1. Analysis of the external environment 2.analysis of the internal environment. Analysis of the external environment, including the general environment, industry branch analysis and then determine the position in the industry branch. And the internal environment, including the evaluation of resources and capabilities of the company. Regarding the second factor, the Strategy of company, strategic management from the perspective of various definitions have been looking at, for example, Mintzberg (1981), the strategy of the ideas and attitudes that have been raised about the strategy and on school development strategy respectively. Chandler (1962), describes the strategy as "long-term objectives, and appropriate decisions in accordance with the objectives and allocate resources so that the desired goals are achieved." It also states that the strategy is a single project, a comprehensive and integrated the strengths and weaknesses of the organization with the relevant environmental opportunities and threats, and achieve the main goals of the organization allows. About a third of the supply and allocation decisions, including capital structure decisions that indicate how the company provides the needed financial resources: debt or equity? Investment decisions (capital budgeting) that managers should be given the growth options in the company, invest. But just as corporations without regard to this issue, decided to make the investment, subject to the surplus or deficit arises when companies invest more growth options in the year, the surplus of investment capital occurred and when companies are not commensurate with the growth of investment, investors have investors have been Dcharksry. And between investment firms and the level of expected investment performance, which was not observed significant deviation. (Biddle et al., 2009) and working capital management decisions in which the efficient management of working capital, the planning and control of the assets and current liabilities in a manner that the risk of inability to pay short-term obligations on the one hand, and to avoid excessive investment in these assets meet on the other side. (Aylchly 2004)

The fourth risk factor is the possibility of losing all or part of the interest or principal, or, in general, volatility of return on investment is called risk (Sharpe, 1985), risks arising from policies and a country's macro-economic factors such as privatization, GDP, etc. or policies at the level of companies, such as how financing, liquidity policies, etc. The company is growth potential. In this regard, although a comprehensive study and general factors affecting the company's performance, it seems necessary, however, because of the extent of such an inquiry, be sure it was a few steps in the study of the effects of environmental factors, policies Sakhtarsrmayh and capital management How cost management strategies in companies that have chosen the field of capital expenditure with respect to the assets at their disposal (the organization) and utilizing of intangible assets (growth options) will have a good performance?

\section{A review of the theoretical and literature}

Concept of business strategy since 1960 has been used, despite widespread adoption is still ambiguous, and in particular in management. Definition of a researcher to researcher Strategy concept is different, but in essence many definitions, the concept of strategy is explained "model, which is the main characteristic related decisions and activities of the organization with its environment and determining factor in achieving the goals "(The Hakansvn,2006). Business strategy in this study refers to "an integrated set of activities aimed at enhancing the long-term strength and capabilities in relation to competitors" is "(Bergeron, 2004). In today's business strategy is traditionally the 
question is that "how we can be competitive and to secure an advantage? "

Strategies are needed to answer the question of "how can we be in a supportive way to our clients added value?

Therefore, this strategy is a complex subject and a different understanding of the strategies that the researchers failed to agree on a basic definition that makes so many people the words of strategy, the program, Politics and the objectives of instead of the them. This strategy separates objectives and our focus on tools used (the pattern of resource allocation) to achieve desired goals

he literature on the strategic orientation of the three approaches to consider: a descriptive approach, approach to classification and comparative approach (Mani et al., 2009) Descriptive approach in trying to describe the unique nature of the holistic strategy to the condition and time. This approach focuses on the methodology of qualitative research is aimed at crushing using case study analysis. In organizational research suggests that this approach to test the theory of its use has been limited because knowledge is not enough to create a standard measurement scale (Morgan, 1998). This view is due to the uniqueness of strategy, organization, environment and temporary conditions, the unit of analysis is limited and can not be generalized. (Morgan, 2003)

The second approach to the study of strategy, classification approach, the approach has to overcome many of the limitations inherent descriptive approach. The company's approach according to the nature of the classified strategies emphatically (Vnkatrmn, 1989), like Porter model (1980) to measure the cost-reduction strategy that includes strategy, differentiation strategy and focus strategy (focused) or typology of Miles and Snow (1978), which included (WT), farsightedness (exploration), analyst, passive (reactive) and concluded that the strategy with analytical, prospective and more performance than defensive strategy of passive (reaction ) will witness (Dsarbv et al., 2004) Classification methodology in management literature has emphasized, it should be noted that such approaches are limited only to compare between groups and of any investigation into his group Yes, and such an approach may be minor differences related to the various aspects of strategy Tbqatsh ignore the competition.

The third strategy evaluation approach, comparative approach. Experts in this approach, to find and measure the key characteristics of strategies (which are called aspects) are trying to

The comparative model to evaluate the strategic orientation, not among different classes, but also deals with aspects of competitive strategy (Morgan, 1998) and to evaluate strategies using multiple dimensions, which are common to all organizations carry. The Rvykrdastratzhy, the relative emphasis placed on each aspect of the company's strategic orientation. As a result, the comparative approach to the limitations of the experimental approach to classification, the business strategy considers only a specific class wins. In the current study is intended business strategy concept of competition and the approach of classifying, using the model Pvrtrastfadh. The first person to be paid specifically to the concept of competitive strategy was none other than Michael Porter. From Porter's vision, to overcome strong opponents in the competition must be equipped with weapons that failure to provide the lowest rates. Porter's theory that explains the theory of the three strategies, Avmtqd the strategies that a company can employ in order to achieve competitive advantages include:

\subsection{Cost management strategy}

The strategy seeks to reduce costs comes over and tries by reducing costs compared with competitors to gain market share. The organization seeks to increase the efficiency seems reckless. The implementation of this strategy is a priority to maintain stable income and to think about innovation and risk-taking companies, but are looking for products and services at competitive prices. Of course not reduce the quality of products and to the benefit of the people. This method uses a management company that can stand up against competitors because customers can find high quality products and lower price.

Companies that have adopted the strategy of cost management, through the creation and sale of lower production costs than their competitors will be able to increase their market share. These 
companies to implement cost management should carry out activities articipate in the creation, production, sale and transportation of products and services, namely better, faster, cheaper and with inputs (input) less than Rqbayshan-participate.

Firms can apply different tactics to achieve cost management. These tactics include: A use of facilities (facilities) on a large scale process improvement 2. minimize production costs 3 . Total Quality Management 4. The optimal use of modeling and control of overhead costs in order to remove the adverse deviations. Some of the techniques Used in this field include lean manufacturing, statistical process control departments cost management, process reengineering, value chain management.

\subsection{Product differentiation strategy}

The implementation of this strategy is to seek the products and services that the industry provides products and services to be distinguished competitors. It is possible to work in a company is advertising, he spoke about the outstanding characteristics of their products, provide exceptional service or use an advanced technology to make your product the way out that is unique. This strategy is targeted at customers that are not at the expense of attention, so the above activities can be beneficial to use different strategies to build the product, it can reduce the intensity of competition and no threat of product substitution for notice Do not producing because customers are loyal to the brand product. Successful execution of this strategy requires costly activities such as research and development work and is a great advertisement

\subsection{Focus strategy}

Porter's strategy in the implementation of the strategy of focusing on a particular kind of product Third, the organization tries to emphasize certain parts of the market or certain groups of purchasers focus. The company will reduce costs and differentiate the product and limit the market to achieve this goal. The characteristics of this strategy can be flexibility in rewarding and intimate relationships with employees, providing services to customers in order to increase consumer loyalty, high authority to staff to contact and meet the needs of customers and the combination of high politics The strategic objectives outlined. The strategy focuses on a small part of the effort is concentrated where the strategies of differentiation and cost leadership achieved. In this study, the effect of the above-mentioned strategy "cost management" in terms of capital expenditure and corporate performance have been studied.

\subsection{Investment decisions}

Director of the company, to identify factors influencing the investment and using them in achieving optimal investment level, ultimately can create efficiency so that investors do not lose profitable opportunities both to obtain the consent of shareholders (Fazary and Hubbard 2; 1988), but markets are inefficient defects that could affect the company's optimal level of investment and, ultimately, the process of "overinvest" or "under-investment" lead. The hypothesis is expressed more or less investment companies that invest less than optimal level, the problem of under-investment and companies that invest more than the optimum level of investment more difficult to suffer. Therefore, the most important factors influencing the level of investments, the assessment is to identify and determine the optimal level of investment, is very important (Tehran Vhsarzadh, 1388). According to the studies, sources of internal financing of the factors that could affect the company's investments (Huang et al., 2011). The firm's reliance on domestic resources through "investment-cash flow sensitivity" of that company is determined. -Jryan Cash investment index for the first time by Fazary et al (Fazary and Hubbard, 1988). Which was introduced by measuring the changes in the company's capital expenditure for a unit change in cash flow, defined Myshvd.bdyn means that fluctuations in the rate of investment to changes in cash flows indicates the sensitivity of investment - flows cash. Light and honest person, investment efficiency through the ratio of sales to capital expenditure ratio of sales to the book value of fixed assets calculated and studied. (Light and honest person; 1389) they believe the company The fixed assets less capital expenditure and 
sales of investments more efficiently has a greater reach.

\subsection{Organization size}

The size of the organization, the size and the activities of the organization, the larger size and broader organization, the greater the perceived reputation of the company as a result, greater access to capital markets for funding will be needed. In other words, the larger the size of the company, the company with the capital markets, lenders and investors more credit will be required to use higher levels of credit and loans. Porter believes that larger companies have access to more resources, in terms of leadership at the expense of competing or trying to cope products and services offer distinctive from competitors, while often smaller companies focus on products and Services are special. (Fred R. David, 2007)

\subsection{Growth Options}

Tylz in 1963 expressed the view that many of the future leaders of the company are very similar to the view that a child of her own. When you ask them that in the next few years are going to attend what to do, they call to say that "bigger". (Ramezani et al, 2001) The term growth, often or is unknown or has many meanings. People often say "growth companies", but it is not always clear. In some cases, this term means sales growth and in some cases revenue growth and asset growth is. High price-to-earnings ratio is also sometimes represents the company's growth. For Kelly, representing growth potential for value creation and growth. But what? Shareholders invest in the company and the book value of their assets (net assets of the company) is representative of the investment. Companies will utilize the company's net assets and operations to increase shareholder value Yabd.svd residual value to book value which is in excess of the capital cost of the measure. Therefore, a logical approach for considering that growth is closely related to the creation of value for shareholders, considerable growth is residual income. Growth company is one of the factors that will lead to profitable growth residues.

\subsection{Organizational Performance}

Many studies have long to reach a suitable criterion for assessing the performance of companies and directors in order to ensure the company is in line with the interests of investors and the de facto basis economic decision-making potential investors and creditors accept. Results obtained from these studies offer four approaches in relation to the performance criteria have led to the following:

Accounting approach: In this approach, the figures contained in the financial statements such as profit, earnings per share, operating cash flows, return on assets and return on equity is used to evaluate the performance (Ansari and Karimi, 2008).

Economic approach: This approach is used in which the economic implications, the performance of an entity with an emphasis on power and profit according to the rate of return on assets and cost of capital rate used is evaluated (Anvari Rostami et al., 2004) . EVA, modified EVA and MVA are in this place.

Integrated approach: In this approach, a combination of accounting and market information used to assess performance as Tobin's Q 1 and the ratio of price to earnings (P / E) (civilian and Asghari, 2006).

Financial management approach: In accordance with this approach, most of the theories of financial management, capital asset pricing model 1 and concepts of risk and return is used. The main emphasis of this approach is to determine the excess return per share (Ansari and Karimi, 2008)

\subsection{Literature Studies Abroad}

Donald Hambrick (1997) to study characteristics of successful strategies of companies in the manufacturing industry, and concluded that the combination of assets and how to use them is an important factor in profitability of the company. He also realized that the characteristics of successful strategies companies like General Theory Porter.

Tom Ktvan Hong et al. (2010) in a study entitled "Communication strategy, capital structure and function," concluded the liquidity strategy, to be significantly related to firm performance. If you are looking for performance management should not waste their time to raise money. Instead, they should focus on the 
management and concluded that affect the capital structure of the company's overall performance.

Studies in Iran Optical person, Y and honest, M. (2010) for the first time in a study entitled "The impact of cost management strategy on longterm financial performance of top companies listed on Tehran Stock Exchange" came to the conclusion that companies are looking for cost management strategy can the ability to maintain strong financial performance gain but long-term it will not.

Brothers Hassanzadeh, Messenger, Salehi right, N. (2012) in a study entitled "The relationship between corporate strategy, capital structure and corporate performance" to conclude that the strategy of sales growth with return on equity and return on assets Myarmlkrd, is a positive relationship. Strategy and liquidity criteria for return on equity, free cash flow per share and return on assets is a positive relationship and capital structure (debt ratio) with the company's free cash flow significantly and positively correlated with return on assets and negative.

Dianati crowbar, Zahra and Pvrchngyz, Mohammad Sadiq. (2013) in a research study of Tasyrbkargyry comprehensive quality management on the financial performance of the company (Case study) using this model as one of the tactics of cost management strategy, as a means to measure the efficiency of the company and improve financial performance, concluded that the TQM model, a change in the process and improve financial performance. Even at a time when running the model, Chshmgyrdr improve the company's performance has not been able to at least stabilize the financial performance.

\section{Hypothesis}

The aim of this study was to investigate the relationship between cost management strategy, organization size and growth opportunities on the financial performance of companies in the Tehran Stock Exchange is trying to achieve the same nutrition might answer the question of how companies cost management strategy in terms of capital expenditure have chosen the the amount of assets at their disposal (the organization) and utilizing of intangible assets (growth opportunities) will have a good performance? In order to find answers to the above questions are presented based on theories, hypotheses have been developed as follows: Hypothesis 1: The relationship between cost management strategy, organization size and growth opportunities there with organizational performance

Hypothesis 1-1: The double standards of efficiency, growth opportunities, firm size and there is a return on assets

Hypothesis 1-2: The double standards of efficiency, growth opportunities, company size and sales growth there

Hypothesis 2: The relationship between cost management strategy, there is a measure of the performance of the organization

Hypothesis 2-1: The double standards of efficiency, size and there is a return on assets.

Hypothesis 2-2: The double standards of efficiency, company size and sales growth there.

Hypothesis 3: The relationship between cost management strategy, growth opportunities exist with the organization's performance

Hypothesis 3-1: The double standards of efficiency, there is opportunity for growth and return on assets.

Hypothesis 3-2: The double standards of efficiency, growth opportunities and sales growth there.

\subsection{Community sample}

The population of the top 100 companies of Tehran Stock Exchange.

Sample of financial information listed companies since the 2009-2013 audited by certified public accountants audit organization or institution that is a member of a sample of 76 companies with a series of conditions for 5 years, was selected.

\subsection{Data collection}

(A) Information on literature and theoretical foundations that were collected through library research

(B) information related to companies in Tehran Stock Exchange is the second part of the information required financial statements with explanatory Vyaddasht the financial statements of the company from 2009 to 2013 was in the field of Web and software Tehran Stock 
Exchange New Software outcomes were collected.

\subsection{Data analysis}

To analyze the data and to evaluate the effects of variables, ARCH and GARCH model is used. Eviews8 in the study of the application
3.4How to measure the variables of the study:

To test the hypothesis, 6 variables as dependent and independent variables were used. How to calculate the variables are as follows:

Table 1: variable Research

\begin{tabular}{|c|c|c|c|}
\hline Type & Variable & Symbol & Calculation method \\
\hline \multirow{2}{*}{$\begin{array}{l}\underset{0}{0} \\
\stackrel{0}{0} \\
\stackrel{0}{0} \\
\stackrel{0}{0} \\
\stackrel{7}{7}\end{array}$} & Return on Assets & ROA & $\begin{array}{l}\mathrm{ROA}_{i t}=\frac{\mathrm{NProf}_{i t}}{\mathrm{TA}_{i t}} \\
\text { NProf } \mathrm{it}_{\mathrm{it}} \text { Net profit of firm } \mathrm{i} \text { at the end of year } \mathrm{t} \\
\mathrm{TA} \text { it: book value of assets of firm } \mathrm{i} \text { at the end of the year } \mathrm{t}\end{array}$ \\
\hline & Sales growth & Sales Growth & $\begin{aligned} & \text { Sales Growth }=\frac{\text { Sales }_{i t}-\text { Sales }_{i t-1}}{\text { Sales }_{i t-1}} \\
& \text { Sales }_{i t} \text { net sales of firm i at the end of year } \mathrm{t} \\
& \text { Sales }_{(\mathrm{it}-1)} \text { : net sales of firm } \mathrm{i} \text { at the end of year } \mathrm{t}-1\end{aligned}$ \\
\hline \multirow{4}{*}{ 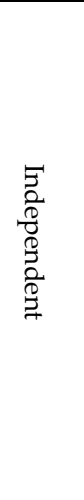 } & Efficiency & Efficienc y & $\begin{array}{l}\text { Efficiency }_{1 i t}=\frac{\text { Sales }_{i t}}{\text { Capexp }_{i t}} \\
\qquad \text { Sales }_{i t} \text { : net sales of firm i at the end of year } t \\
\text { Capexp_it: capital expenditure of firm } i \text { at the end of year } t\end{array}$ \\
\hline & & & $\begin{array}{l}\text { Efficiency }_{2 i t}=\frac{\text { Sales }_{i t}}{\mathrm{TFC}_{i t}} \\
\qquad \text { Sales } \\
\text { it }\end{array}$ \\
\hline & Growth option & Growth & $\begin{array}{l}\text { Growth }_{i t}=\frac{\left(\mathrm{TA}_{i t}+\mathrm{MVE}_{i t}\right)-\mathrm{BVE}_{i t}}{\mathrm{TA}_{i t}} \\
\mathrm{MVE}_{\mathrm{it}}: \text { market value of equity of firm i at the end of the year } \mathrm{t} \text { that is, multiplying } \mathrm{t} \\
\mathrm{BVE}_{\mathrm{it}} \text { : book value of equity of firm } \mathrm{i} \text { in } \mathrm{t} \\
\mathrm{TA} \text { it: book value of assets of firm } \mathrm{i} \text { at the end of the year } \mathrm{t}\end{array}$ \\
\hline & Size & Size & $\begin{array}{l}\text { Size }_{i t}=\log _{10}\left(\mathrm{TA}_{i t}\right) \\
\mathrm{TA} \text { it: book value of assets of firm } \mathrm{i} \text { at the end of the year } \mathrm{t}\end{array}$ \\
\hline
\end{tabular}

\section{The results of hypothesis tests}

The main hypothesis of the first significant correlation between cost management strategy, growth opportunities, as there are organizations and company performance The main hypothesis is designed to test the hypothesis that the first two performance criteria is based on 2 types. And to examine the relationship strategy, growth opportunities and the size of company that focuses on performance

4.1 First hypothesis: the double standards of efficiency, growth opportunities, firm size and there is a return on assets

$$
\begin{aligned}
& \quad R O A_{i t}=\alpha+\beta_{1} E F F_{1 i t}+\beta_{2} E F F_{2 i t}+\beta_{3} G R O_{i t}+ \\
& \beta_{4} S I_{i t}+u_{i t} \\
& \sigma_{i t}^{2}=\aleph_{0}+\aleph_{1} u_{i t-1}^{2}+\aleph_{2} \sigma_{i t-1}^{2}
\end{aligned}
$$

Table 2: Results of the first hypothesis mean equation

\begin{tabular}{|c|c|c|c|c|c|}
\hline \multicolumn{7}{|c|}{ The average equation } \\
\hline VARIABLE & Factor model & Coefficient & Z statistics & P-Value & RESULT \\
\hline Constant & $\alpha$ & $0.000192-$ & $0.065-$ & 0.948 & \\
\hline Efficiency1 & $1 \beta$ & $06-2.53 \mathrm{E}-$ & $9.435-$ & 0 & Significant test \\
\hline Efficiency 2 & $2 \beta$ & $07-8.36 \mathrm{E}$ & 9.428 & 0 & Significant test \\
\hline Growth option & $3 \beta$ & 0.025 & 6.562 & 0 & Significant test \\
\hline Size & $4 \beta$ & 0.1599 & 10.434 & 0 & Significant test \\
\hline \multicolumn{7}{|l}{} \\
\hline
\end{tabular}

Table 3: results of the first secondary hypothesis variance equation 


\begin{tabular}{|c|c|c|c|c|c|}
\hline \multicolumn{7}{|c|}{ The variance equation } \\
\hline VARIABLE & $\begin{array}{c}\text { Factor } \\
\text { model }\end{array}$ & Coefficient & Z statistics & P-Value & RESULT \\
\hline Constant & $0 \lambda$ & 0.0027 & 8.302 & 0 & Significant test \\
\hline $\begin{array}{c}\text { Square sentences } \\
\text { interval error (-1) }\end{array}$ & $1 \lambda$ & 0.794 & 6.485 & 0 & Significant test \\
\hline $\begin{array}{c}\text { Delayed } \\
\text { conditional } \\
\text { variance (-1) }\end{array}$ & $2 \lambda$ & 0.1078 & 2.316 & 0.0205 & Significant test \\
\hline & & \multicolumn{7}{|c|}{$\begin{array}{c}0.065 \\
\end{array}$} \\
\hline
\end{tabular}

4.1.1 Interpretation of results: Due to the significant level statistic z $(0.000)$ in the equation, the average of all other factors constant less than acceptable level of error $(5 \%)$ and the indication of the return on assets is a work of Arch Model by the independent variable (performance, growth opportunities and the size of the organization) is described. The variance of the associated errors. Also in the equation of variance, the square error is interrupted and the conditional variance interrupted at a high level individually significant positive coefficient is Hstnd.v. Because conditional variance conditional variance to break the influence it is clear that we have a work of continuous arch. According to the statistics of $Q$ and probability $(0.065)$ shares in its lack of acceptance $(5 \%)$, so we have time series is static.negative effect on return on assets.

4.2 The second sub-hypothesis: the double standards of efficiency, growth opportunities, company size and sales growth there

$$
\begin{array}{r}
S G_{i t}=\alpha+\beta_{1} E F F_{1 i t}+\beta_{2} E F F_{2 i t}+ \\
\beta_{3} G R O_{i t}+\beta_{4} S I_{i t}+u_{i t}
\end{array}
$$

Table 4: The results of the second test average equation subhypotheses

\begin{tabular}{|c|c|c|c|c|c|}
\hline \multicolumn{7}{|c|}{ The average equation } \\
\hline VARIABLE & $\begin{array}{c}\text { Factor } \\
\text { model }\end{array}$ & Coefficient & Z statistics & P-Value & RESULT \\
\hline Constant & $\alpha$ & 0.0158 & 1.0769 & 0.2815 & \\
\hline Efficiency1 & $1 \beta$ & $05-3.19 \mathrm{E}$ & 18.779 & 0 & Significant test \\
\hline Efficiency2 & $2 \beta$ & $05-2.41 \mathrm{E}$ & 9.301 & 0 & Significant test \\
\hline Growth options & $3 \beta$ & 0.111 & 7.308 & 0 & Significant test \\
\hline Size & $4 \beta$ & 0.1973 & 2.095 & 0.0362 & Significant test \\
\hline & coefficient of determination 0.0041 and adjusted coefficient of determination \\
& \multicolumn{7}{|l}{} \\
\hline
\end{tabular}

Table 5: results of the second sub-hypothesis variance equation

\begin{tabular}{|c|c|c|c|c|c|}
\hline \multicolumn{7}{|c|}{ The variance equation } \\
\hline VARIABLE & Factor model & Coefficient & Z statistics & P-Value & RESULT \\
\hline Constant & $0 \lambda$ & 0.0758 & 10.2833 & 0 & Significant test \\
\hline $\begin{array}{c}\text { Square sentences } \\
\text { interval error (-1) }\end{array}$ & $1 \lambda$ & 1.492 & 10.8354 & 0 & Significant test \\
\hline \multicolumn{7}{|c|}{} & Q base to 122 intervals (1/3 Total views) equal to 136.77 and the probability of \\
\end{tabular}

4.2.1 Interpretation of results: Due to the significant level statistic $\mathrm{z}(0.000)$ in the mean equation, all coefficients except the constant coefficient of less than acceptable error level (5\%) and this implies the existence of an arch effect on sales growth by the independent variable 
(performance, growth opportunities and the size of the organization) is explained. In addition, the variance, the variance of delay (delay) of the square error of the gap is positive and highly significant. The sales growth is due to the arch in your error is correlated with respect to the $\mathrm{Q}$ statistic and probability (0.171) shares in the absence of acceptance (5\%). Therefore, our time series is stationary

Two main hypotheses: correlation between cost management strategy, organization and corporate performance is measured
Two main hypotheses have been developed to test the hypothesis is based on two types of performance criteria. And to examine the relationship strategy, and firm size on the performance of deals

4.3 First hypothesis: the double standards of efficiency, size and there is a return on assets For this test, we examined the effect of omitted variables in the model

$$
\begin{aligned}
& R O A_{i t}=\beta_{1} E F F_{1 i t}+\beta_{2} E F F_{2 i t}+\beta_{3} S I_{i t}+u_{i t} \\
& \sigma_{i t}^{2}=\aleph_{0}+\aleph_{1} u_{i t-1}^{2}+\aleph_{2} \sigma_{i t-1}^{2}
\end{aligned}
$$

Table 6: Results of omitted variables (growth opportunities) equation was first hypothesis

\begin{tabular}{|c|c|c|c|c|c|}
\hline \multicolumn{7}{|c|}{ The average equation } \\
\hline VARIABLE & $\begin{array}{c}\text { Factor } \\
\text { model }\end{array}$ & Coefficient & Z statistics & P-Value & RESULT \\
\hline Efficiency1 & $1 \beta$ & $06-2.64 \mathrm{E}-$ & $9.452-$ & 0 & Significant test \\
\hline Efficiency2 & $2 \beta$ & $07-7.97 \mathrm{E}$ & 9.506 & 0 & Significant test \\
\hline Size & $3 \beta$ & 0.148 & 8.523 & 0 & Significant test \\
\hline \multicolumn{7}{|l}{} \\
\hline
\end{tabular}

Table 7: Results of omitted variables (growth opportunities) variance equation first hypothesis

\begin{tabular}{|c|c|c|c|c|c|}
\hline \multicolumn{7}{|c|}{ The variance equation } \\
\hline VARIABLE & Factor model & Coefficient & Z statistics & P-Value & RESULT \\
\hline Constant & $0 \lambda$ & 0.0033 & 10.127 & 0 & Significant test \\
\hline $\begin{array}{c}\text { Square sentences } \\
\text { interval error (-1) }\end{array}$ & $1 \lambda$ & 0.83 & 7.073 & 0 & Significant test \\
\hline $\begin{array}{c}\text { Delayed conditional } \\
\text { variance (-1) }\end{array}$ & $2 \lambda$ & 0.0498 & 1.302 & 0.192 & \\
\hline & \multicolumn{7}{|c|}{ Mqdaramarh likelihood of 29.171 and the probability of 0.00 } \\
\hline
\end{tabular}

4.3.1 Interpretation of Results: As can be seen removing variables growth opportunities caused the variance equation, coefficient of variation, if the delay is not significant. The coefficient of determination test of likelihood ratio also fell model Likelihood ratio)) is significant at the level of zero is the correct functional form, so it can not be excluded from the model of growth opportunities

4.4 The second hypothesis: the double standards of efficiency, company size and sales growth there For this test, we examined the effect of omitted variables in the model

$$
\begin{aligned}
& S G_{i t}=\beta_{1} E F F_{1 i t}+\beta_{2} E F F_{2 i t}+\beta_{3} S I_{i t}+u_{i t} \\
& \sigma_{i t}^{2}=\aleph_{0}+\aleph_{1} u_{i t-1}^{2}
\end{aligned}
$$

Table 8: Results of omitted variables (growth opportunities) equation was second hypothesis

\begin{tabular}{|c|c|c|c|c|c|}
\hline \multicolumn{7}{|c|}{ The average equation } \\
\hline VARIABLE & Factor model & Coefficient & Z statistics & P-Value & RESULT \\
\hline Efficiency1 & $1 \beta$ & $05-4.26 \mathrm{E}$ & 17.902 & 0 & Significant test \\
\hline Efficiency2 & $2 \beta$ & $05-2.42 \mathrm{E}$ & 8.445 & 0 & Significant test \\
\hline Size & $3 \beta$ & 0.1973 & 2.467 & 0.0136 & Significant test \\
\hline \multicolumn{7}{|c|}{ coefficient of determination-0.024and adjusted coefficient of determination -0.03 } \\
\hline
\end{tabular}

Table 9: Results of omitted variables (growth opportunities) variance equation second hypothesis

\begin{tabular}{|c|c|c|c|c|c|}
\hline \multicolumn{5}{|c|}{ The variance equation } \\
\hline VARIABLE & Factor model & Coefficient & Z statistics & P-Value & RESULT \\
\hline
\end{tabular}




\begin{tabular}{|c|c|c|c|c|c|}
\hline Constant & $0 \lambda$ & 0.0787 & 9.684 & 0 & Significant test \\
\hline $\begin{array}{l}\text { Square sentences } \\
\text { interval error (-1) }\end{array}$ & $1 \lambda$ & 1.578 & 11.13 & 0 & Significant test \\
\hline & \multicolumn{5}{|c|}{ Mqdaramarh likelihood of 31.958 and the probability of 0.00 } \\
\hline
\end{tabular}

4.4.1Interpretation of Results: As can be seen removing variables growth opportunities and marks a significant effect on the factors in the equation, but it did not mean and variance ratio test of likelihood ratio also dropped Model Likelihood ratio)) in significant levels. This functional form is correct. This variable can be excluded from the model of growth opportunities

The main hypothesis of the third: a significant relationship between cost management strategy, growth opportunities and the company's performance there
The main hypothesis is designed to test the hypothesis third two performance criteria is based on 2 types. And to examine the relationship strategy and growth opportunities that focuses on performance

4.5First hypothesis: the double standards of efficiency, there is opportunity for growth and return on assets

$R O A_{i t}=\beta_{1} E F F_{1 i t}+\beta_{2} E F F_{2 i t}+\beta_{3} G R O_{i t}+u_{i t}$ $\sigma_{i t}^{2}=\aleph_{0}+\aleph_{1} u_{i t-1}^{2}+\aleph_{2} \sigma_{i t-1}^{2}$

Table 10: Results of omitted variables (size) equation was first hypothesis

\begin{tabular}{|c|c|c|c|c|c|}
\hline \multicolumn{7}{|c|}{ The average equation } \\
\hline VARIABLE & Factor model & Coefficient & Z statistics & P-Value & RESULT \\
\hline Efficiency1 & $1 \beta$ & $06-3.21 \mathrm{E}-$ & $11.775-$ & 0 & Significant test \\
\hline Efficiency 2 & $2 \beta$ & $07-6.02 \mathrm{E}$ & 6.538 & 0 & Significant test \\
\hline Growth options & $3 \beta$ & 0.024 & 4.834 & 0 & Significant test \\
\hline & coefficient of determination0.1117and adjusted coefficient of determination 0.1069 \\
\hline
\end{tabular}

Table 11: Results of omitted variables (size) variance equation first hypothesis

\begin{tabular}{|c|c|c|c|c|c|}
\hline \multicolumn{7}{|c|}{ The variance equation } \\
\hline VARIABLE & Factor model & Coefficient & Z statistics & P-Value & RESULT \\
\hline Constant & $0 \lambda$ & 0.0028 & 6.775 & 0 & Significant test \\
\hline $\begin{array}{c}\text { Square sentences } \\
\text { interval error (-1) }\end{array}$ & $1 \lambda$ & 0.735 & 7.085 & 0 & Significant test \\
\hline $\begin{array}{c}\text { Delayed conditional } \\
\text { variance (-1) }\end{array}$ & $2 \lambda$ & 0.173 & 3.023 & 0.0025 & Significant test \\
\hline \multicolumn{7}{|c|}{ Mqdaramarh likelihood of46.093 and the probability of 0.00} \\
\hline
\end{tabular}

4.5.1Interpretation of Results: As can be seen removing a significant effect on the variable size and sign of coefficients in the equation did not mean and variance and the coefficient of determination of 0.106 to 0.1117 was promoted and improved version of the likelihood ratio statistic Likelihood ratio)) in significant levels is therefore functional form is correct. Therefore, the size of the company can be removed from the model

4.6The second hypothesis: the double standards of efficiency, there is opportunity for growth and sales growth For this test, we examined the effect of omitted variables in the model

$$
\begin{aligned}
& S G_{i t}=\beta_{1} E F F_{1 i t}+\beta_{2} E F F_{2 i t}+\beta_{3} G R O_{i t}+u_{i t} \\
& \sigma_{i t}^{2}=\aleph_{0}+\aleph_{1} u_{i t-1}^{2}
\end{aligned}
$$

Table 12: Results of omitted variables (size) equation was second hypothesis

\begin{tabular}{|l|l|l|l|l|l|}
\hline \multicolumn{5}{|c|}{ The average equation } \\
\hline VARIABLE & Factor model & Coefficient & Z statistics & P-Value & RESULT \\
\hline
\end{tabular}




\begin{tabular}{|c|c|c|c|c|l|}
\hline Efficiency 1 & $1 \beta$ & $05-3.12 \mathrm{E}$ & 18.981 & 0 & Significant test \\
\hline Efficiency 2 & $2 \beta$ & $05-2.37 \mathrm{E}$ & 9.07 & 0 & Significant test \\
\hline Growth options & $3 \beta$ & 0.1107 & 7.245 & 0 & Significant test \\
\hline & coefficient of determination 0.0097 and adjusted coefficient of determination 0.004 \\
\hline
\end{tabular}

Table 13: Results of deleted variables (size) variance equation second hypothesis

\begin{tabular}{|c|c|c|c|c|c|}
\hline \multicolumn{7}{|c|}{ The variance equation } \\
\hline VARIABLE & Factor model & Coefficient & Z statistics & P-Value & RESULT \\
\hline Constant & $0 \lambda$ & 0.074 & 11.113 & 0 & Significant test \\
\hline $\begin{array}{c}\text { Square sentences } \\
\text { interval error (-1) }\end{array}$ & $1 \lambda$ & 1.523 & 10.904 & 0 & Significant test \\
\hline \multicolumn{7}{|c|}{ Mqdaramarh likelihood of3.475 and the probability of 0.063} \\
\hline
\end{tabular}

4.6.1 Interpretation of Results: As can be seen removing a significant effect on the variable size and sign of coefficients in the equations mean and variance of 0.0041 to 0.0097 not the determining model increased the amount of statistics, likelihood ratio Likelihood ratio)) in significant 0.063 level it is not wrong functional form. The variable size can not be removed from the model.

\section{Analysis and interpretation of results and recommendations}

5.1 Analysis and interpretation of results of the first hypothesis

Return on Assets considerable turbulence, dynamic (time-varying) and correlated with time to exhibit growth opportunities and the size of the organization. In this respect, effectiveness criteria 1 positive factor and effectiveness criteria 2 negative factor influence on return on assets.

Sales growth disturbance associated with the exhibit. In this regard, performance standards and growth opportunities and the size of the positive factors have an impact on sales growth. However, this connection is very weak.

5.2 Analysis and interpretation of test results of the second hypothesis

Sales growth and cost management strategy as the behavioral effects associated with their time show

5.3 Analysis and interpretation of the results of the third main hypothesis

Return on assets under management strategy and growth opportunities cost them considerable turbulence behavioral dynamic (time-varying) and their associated remnants of the show.

\subsection{Practical suggestions}

Given the significance of the first hypothesis, in assessing the performance of companies listed on the exchange period, depending on the stock exchange which uses performance criteria unruly behavior at a time (variable remnants) and correlated with the return on assets by strategic cost management and growth opportunities described the behavior associated with the sales growth of the company's cost management strategy and firm size described by the attention.

Brasas second hypothesis, the results indicate that large firms of cost management strategy can be applied to describe the sales growth

$\mathrm{Br}$ third hypothesis applied in the corporate cost management strategies depending on their growth opportunities as well as use (not) swings positive (negative) describes the return on assets

\subsection{Research Proposals}

According to the first hypothesis, the impact of supply and resource allocation decisions, including decisions on working capital entered and checked

According to the second hypothesis to determine the causes of changes in sales growth correlated remnants of the operating environment must be examined.

According to the third hypothesis, since the volatility of asset returns can be gained from adopting risks in different periods. Therefore, in order to consider the effects of risk, return on assets, the risk as an independent variable can be in the equation conditional average

\section{References}

Azerbaijani, Karim. Soroush friend, legend. Help

S., S.. "Find the best measure of financial 
performance", Journal of the auditor, in Issue 52

BEYGI Nia, AR. Front, E. (2012) "The tools and techniques of strategic management accounting", National Conference of accounting, financial management and investment

Rbsalhy, M. Ashraf M. (2011). Investment-cash flow sensitivity of cash reserves in listed companies in Tehran Stock Exchange. Journal of Financial Accounting. Issue III, pp. 75-94

optic person, Y., honest, M. (2010) "The effect of the financial performance of the long-term cost management strategies top companies listed in Tehran Stock Exchange", the second International Conference on consultants and financial managers

Baker, M., Ruback, R., and Wurgler, J. (2007). Behavioral Corporate Finance. Handbook of corporate finance: Empirical corporate finance, $1: 145,86$.

Joseph P. Ogden, Shanhong Wu. (2013). "Reassesing The Effect Of Growth Options On Leverage", Journal Of Corporate Finance 23 (2013) 182-195

Kramer, L.A and Liao, C.M. (2012). The Cost of False Bravado: Management Overcon_dence and its Impact on Analysts' Views. North American Finance Conference.

Carolin, C. Rovena, S. (2013) "Measuring performance in the third sector", Qualitative Research in Accounting \& Management, Vol. 10 Iss: 3/4, pp.196 - 212 